\title{
Probiotic Yogurt with Brazilian Red Propolis: Physicochemical and Bioactive Properties, Stability, and Shelf Life
}

\author{
Marly S. Santos, Leticia M. Estevinho, Carlos Alfredo L. Carvalho, Jorge S. Morais, Antonio Leandro S. Conceição, \\ Vanessa B. Paula, Karina Magalhães-Guedes, and Rogeria C. C. Almeida밀
}

\begin{abstract}
This study aimed to evaluate the quality parameters in probiotic yogurt produced with Brazilian red propolis to replace potassium sorbate used in conventional yogurt (CY). Microbiological stability and shelf life, physicochemical properties ( $\mathrm{pH}$, acidity, chemical composition, and fatty acids), and bioactive properties (phenolic compounds and antioxidant activity) were evaluated. The addition of red propolis $(0.05 \%)$ to replace the potassium sorbate did not change the $\mathrm{pH}$, acidity, fatty acid profile, chemical composition, or shelf life. Microbiological stability of at least 28 days was achieved, while a drastic reduction in the lactic acid bacteria content was observed in the CY during refrigeration storage. Phenolic total contents were higher than those of the control, and consequently, yogurt with red propolis showed higher antioxidant activity.
\end{abstract}

Keywords: stability, potassium sorbate, fermentation, lactic acid bacteria, additive

Practical Application: The study indicates that Brazilian red propolis at $0.05 \%$ concentration to replace the potassium sorbate is an efficient alternative for use in yogurt production. The knowledge acquired about these types of Brazilian propolis provides an important contribution to food research in the discovery of new functional products to the market, seeking a healthier diet. Therefore, the produced yogurt proves to be an innovative product with functional and probiotic potential to be placed on the market.

\section{Introduction}

Yogurt is recognized as one of the most used foods in the diet of Brazilians. However, in its formulation, chemical additives such as potassium sorbate, sodium benzoate, and their mixture are commonly used as preservatives with broad-spectrum activity against yeasts and molds (Koc, Silici, Mutlu-Sariguzel, \& Sagdic, 2007). Although they are permitted by Brazilian legislation and considered safe, studies have shown adverse reactions in consumers, such as hyperactivity in children and metabolic disorders, among others (Ribeiro, 2010).

Yogurt frequently carries probiotics (Champagne, Adriano Gomes da Cruz, \& Daga, 2018). Probiotics are live microorganisms that, when administered in appropriate amounts, have ability in improving the general health and well-being of the consumers (Hill et al., 2014; Ranadheera, Naumovski, \& Ajlouni, 2018).

Lactic acid bacteria from genera Bifidobacterium and Lactobacillus have been widely recognized as probiotics (Ranadheera et al.,

JFDS-2019-1074 Submitted 7/4/2019, Accepted 10/15/2019. Authors Santos and Almeida are with School of Nutrition, Federal Univ. of Bahia, Rua Basilio da Gama, s/n, Canela, Cep: 40.110-160, Salvador, BA, Brazil. Authors Estevinho, Morais, and Paula are with CIMO-Mountain Research Center, Dept. of Biology and Biotechnology, School of Agriculture, Polytechnic Inst. of Bragança., Campus Santa Apolónia, Cep: 5300-253. Bragança, Portugal. Authors Carvalho and Conceição are with Center of Agricultural Sciences, Environmental and Biological, Federal Univ. of Bahia Reconcavo, Rua Rui Barbosa, n 710, Centro, Cep: 44.380-000. Cruz das Almas, Bahia, Brazil Author Magalhães-Guedes is with Dept. of Bromatological Analysis, Pharmacy Faculty, Federal Univ. of Bahia, Barão of Geremoabo Street, s/n, Ondina, Cep: 40.171-970. Salvador, Bahia, Brazil. Direct inquiries to author Almeida (E-mail: rogeriac@ufba.br).
2018). According to Aryana and Olson (2017), yogurt with probiotics Lactobacillus acidophilus La5 and Bifidobacterium lactis Bb12 consumed by individuals with type 2 diabetes mellitus, led to a decrease in total serum cholesterol and in low-density lipoprotein cholesterol.

In the past few years, yogurt has been produced with addition of polyphenol from fruits and fruit seed, dietary fiber, and botanical extracts to improve its quality and bioactivity (Liu, 2018). Recently, there are been an increased interest in bioactive principles in raw materials for the development of stable functional products (Molina, Lima, Moraes, \& Pinho, 2019), and new trends may emerge in the production of functional and healthy dairy products (Yildiz \& Ozcan, 2019).

Increasing the shelf life of a food product is a crucial role in food processing, as this reduces food and waste losses (Asioli et al., 2017). Food additives can extend shelf life, improve taste, restore colors, etc. However, the relationship between consumers and food additives has always been problematic (Carocho, Morales, \& Ferreira, 2015).

In general, consumers prefer food without additives, or "free from" artificial additives/ingredients (Carocho, Barreiro, Morales, \& Ferreira, 2014) and a new approach in consumer perception about food products has emerged, the so-called "clean label" (Cheung et al., 2016). Clean label has driven the food industry to communicate whether a certain ingredient or additive is not present or if the food has been produced using a more "natural" production method (Asioli et al., 2017).

Currently, some alternatives for food preservation have been sought, among which bee products such as propolis stand out. Propolis is a product derived from resins collected from the 
resinous shoots or exudates of some plants by Apis millifera L. bees (Silva et al., 2013). Brazil is a major producer and exporter of propolis collected by Apis millifera (Pontes, Vasconcelos, Diniza, \& Pessôa, 2018).

Brazilian propolis presents great diversity due to the variations of available flora and is classified into 13 types based on its chemical constitution and antimicrobial and antioxidant activities. The most recent type of propolis classified, the 13th type, is called "red propolis" due to its intense red coloration (Daleprane \& Abdalla, 2013). This kind of propolis is found along the sea and coasts of rivers in northeast Brazil, and its coloration is mainly due to oxidation of the exudates in Dalbergia ecastophyllum (L.) collected by bees (Cabral et al., 2009; Daugsch, Moraes, Fort, \& Park, 2008). This species is also identified by its main constituent, the isoflavone formononetine (7-hydroxy4'methoxyisoflavone; De-Melo, Matsuda, \& Almeida-Muradian, 2012).

Several groups of compounds have been identified in Brazilian red propolis, including isoflavonoids, pterocarpanes, chalcones, flavanone (Liquiritigenina), prenylated benzophenones, terpenes, and tannins (Lopez et al., 2015). Red propolis is known for its benefits to human health and the phenolic compounds present in the propolis have received attention because of their relationship with its antioxidant and antimicrobial properties (Jansen-Alves et al., 2019). Flavonoid compounds are mainly responsible for the anti-inflammatory, antithrombotic, vaso-protective, gastroprotective, and anti-free radical actions, in addition to acting as a modulator of allergic reactions (Freires, De Alencar, \& Rosalen, 2016). Therefore, the antimicrobial and antioxidative properties of propolis are of great value to the food industry due to the possibility of producing delayed lipid oxidation and a positive effect on the stability and shelf life of products (Silva et al., 2013).

Considering the concerns of consumers and the search for healthier foods, without the addition of chemical substances, the present study aimed to evaluate the use of Brazilian red propolis extract as an alternative for the preservation of yogurt, a product consumed on a large scale by Brazilian people.

\section{Materials and Methods}

\section{Brazilian red propolis sample}

The samples used in this study ( $n=5 ; 300 \mathrm{~g}$ each one) consisted of crude extracts of Brazilian red propolis produced by Apis mellifera L. bees, collected from Canavieiras city (S 15 $40^{\prime} 30^{\prime \prime}$ and W $\left.38^{\circ} 56^{\prime} 50^{\prime \prime}\right)(n=4)$ and Ilhéus city (S 14 $4^{\circ} 47^{\prime} 20^{\prime \prime}$ and W $\left.39^{\circ} 02^{\prime} 58^{\prime \prime}\right)(n=1)$, Bahia state, northeast Brazil, and provided by the INSECTA laboratory of the Federal University of Bahia Recôncavo (UFRB).

The Brazilian red propolis was initially macerated, and subsequently, a $1 \mathrm{~g}$ aliquot was placed in a Falcon tube with $12.5 \mathrm{~mL}$ of $70 \%$ ethyl alcohol, vortexed (Loccus, 3800) and allowed to stand for approximately $12 \mathrm{hr}$. The extraction was performed in an ultrasonic bath (Thorton, 345) for $60 \mathrm{~s}$, followed by centrifugation for $5 \mathrm{~min}$ at $800 \times g$ (SPLabor, 154). After $1 \mathrm{hr}$, the sample was filtered through a Whatman no. 1 filter directly into a Petri dish and placed in an exhaust hood (temperature ranged from 19 to $21^{\circ} \mathrm{C}$ ) (Permution, CEO710) for $24 \mathrm{hr}$ until total evaporation of the ethyl alcohol. The obtained dried extract was packed in Eppendorf tubes and frozen at $-20{ }^{\circ} \mathrm{C}$ (Park, Ikegari, Abreu, \& Alcici, 1998).
Determination of minimum inhibitory concentration (MIC) and minimum biocide concentration (MBC)

The concentration of red propolis chosen for yogurt production was determined using the MIC and MBC tests. For the analysis, we used clinical isolates belonging to the microorganism collection of Agricultural College of Bragança, Portugal (ESA), and American Type Collection (ATCC): Staphylococcus aureus (ESA 321), Salmonella Enteritidis (ESA 87), Candida albicans (ESA 115), S. aureus (ATCC 43300), S. enteritidis (ATCC 13076), and C. albicans (ATCC 10231).

The inoculums and serial dilutions were prepared, and the MIC was determined by using brain-heart infusion (BHI) broth and yeast extract - peptone-dextrose (YEPD) broth, for bacteria and yeast, respectively. In each well of 96-well polystyrene microplates was placed $100 \mu \mathrm{L}$ of the red propolis solubilized in dimethyl sulfoxide (DMSO 2.5\%, v/v) (adapted from Morais, Moreira, Feas, \& Estevinho, 2011) at different concentrations $(25 \mu \mathrm{g} / \mathrm{mL}$, $50 \mu \mathrm{g} / \mathrm{mL}, 100 \mu \mathrm{g} / \mathrm{mL}, 500 \mu \mathrm{g} / \mathrm{mL}, 1,000 \mu \mathrm{g} / \mathrm{mL}, 2,500 \mu \mathrm{g} / \mathrm{mL}$, $5,000 \mu \mathrm{g} / \mathrm{mL}, 10,000 \mu \mathrm{g} / \mathrm{mL}, 12,500 \mu \mathrm{g} / \mathrm{mL}$, and $15,000 \mu \mathrm{g} / \mathrm{mL}$ ) and added $100 \mu \mathrm{L}$ of the suspension of the microorganism test; $100 \mu \mathrm{L}$ of culture medium with $100 \mu \mathrm{L}$ of microorganism test was used as positive control and $200 \mu \mathrm{L}$ of culture medium without microorganism as negative control. The microplates were incubated at $37{ }^{\circ} \mathrm{C}$ for $24 \mathrm{hr}$ for bacteria and $48 \mathrm{hr}$ for yeasts. After that, $20 \mu \mathrm{L}$ of 2, 3, 5-triphenytetrazolium chloride (TTC) $0.5 \%$ $(\mathrm{m} / \mathrm{v})$ dye were added in all wells and a new incubation step was carried out for 2 and $3 \mathrm{hr}$ for bacteria and yeasts, respectively (Tsukatani et al., 2008). MIC was defined as the lowest extract concentration that prevented the color change of the medium and exhibited complete inhibition of microbial growth. From each well of the microplate that showed no visible growth and/or color change, $20 \mu \mathrm{L}$ aliquots were pour plated onto Petri dishes and incubated at $37^{\circ} \mathrm{C}$ for $24 \mathrm{hr}$ (bacteria) and $48 \mathrm{hr}$ (yeasts). MBC was determined in plaques where growth was less than or equal to $10 \mathrm{CFU}$. The results were expressed as MIC $(\mu \mathrm{g} / \mathrm{mL})$ and $\mathrm{MBC}$ $(\mu \mathrm{g} / \mathrm{mL})$. The experiments were run in triplicate for each strain.

\section{Preparation of probiotic yogurts}

The yogurt produced was of the "stirril yogurt" type and formulated with a commercial lactic culture containing strains, the $L$. acidophilus, $1 \times 10^{6} \mathrm{UFC} / \mathrm{g}$; Bifidobacterium, $1 \times 10^{6} \mathrm{UFC} / \mathrm{g}$; and Streptococcus thermophilus, following recommendations of the manufacturer (BioRich ${ }^{\circledR}$, Christian Hansen, Horsholm, Denmark). First, $1,000 \mathrm{~mL}$ of whole UHT milk and powdered milk $(1 \%$, $\mathrm{w} / \mathrm{v})$ was boiled and sugar $(12.6 \%, \mathrm{w} / \mathrm{v})$ was added. The samples were subjected to rapid cooling until reaching $42 \pm 2{ }^{\circ} \mathrm{C}$, when the lactic acid culture was added $(0.04 \%, \mathrm{w} / \mathrm{v})$. The products were placed in hermetic glass containers (240 g capacity) (Duran $\odot$ Mainz, Germany) and kept in an incubator (VWR INCU-Line) at $42 \pm 2{ }^{\circ} \mathrm{C}$ for $6 \mathrm{hr}$. The samples were transferred to a refrigerator $\left(4 \pm 2{ }^{\circ} \mathrm{C}\right)$ and allowed to stand for up to $48 \mathrm{hr}$. Afterward, the curd was broken, and potassium sorbate $(0.1 \%, \mathrm{w} / \mathrm{v})$ and strawberry pulp $(10 \%, \mathrm{w} / \mathrm{v})$ were added for the conventional yogurt (CY). For the yogurt with red propolis (YRP), the crude extract $(0.05 \%, \mathrm{w} / \mathrm{v} ; 0.046 \%, \mathrm{w} / \mathrm{w})$ and pasteurized strawberry pulp $(10 \%, w / v)$ were added. Additionally, samples without strawberry pulp were prepared as YRP2. Yogurt sample maintenance was carried out at $4 \pm 2{ }^{\circ} \mathrm{C}$ (adapted from Robert, 2008).

\section{Physicochemical properties}

Physicochemical properties were determined, in triplicate, in samples storage at 0 (zero), 14, and 28 days. 
The $\mathrm{pH}$ was determined directly from the samples using a potentiometer (Mettler Toledo), and the acidity was determined by titration with $0.08 \mathrm{~N} \mathrm{NaOH}$ in the presence of phenolphthalein and expressed as percentage of lactic acid.

Chemical composition was determined using traditional methods. The fixed mineral residue (ash) was determined by subjecting the samples to a temperature of $550^{\circ} \mathrm{C}$ until constant weight, and moisture by gravimetric method, based on the weight loss of the material when heated to $105^{\circ} \mathrm{C}$. The total protein was determined by the Kjeldahl method, by multiplying the nitrogen content by the factor 6.38, and lipid was quantified by the Soxhlet method (AOAC, 2012). The carbohydrate content was calculated by the following difference Equation (1):

$$
\% \text { Carbohydrates }=100-(\% \text { ash }+\% \text { proteins }+\% \text { lipids }) .
$$

Results were expressed as $\mathrm{g} / 100 \mathrm{~g}$.

\section{Fatty acids profile}

The profile of the fatty acids was determined by gas-liquid chromatography (DANI GC 1000) equipped with a split/splitless injector (Barros et al., 2013), at time 0 and 28 days.

The components were separated on a capillary column ( $\mathrm{Ze}-$ bron, ZB-FAME) of $3 \mathrm{~m}$ long, $5 \mathrm{~m}$ of precolumn, an internal diameter of $0.25 \mathrm{~mm}$, and a film thickness of $0.20 \mu \mathrm{m}$. The operating conditions were the initial temperature of the column was $100{ }^{\circ} \mathrm{C}$, which was held for $2 \mathrm{~min}$, and then a $10^{\circ} \mathrm{C} / \mathrm{min}$ ramp was employed to $140^{\circ} \mathrm{C}$, followed by a $3{ }^{\circ} \mathrm{C} / \mathrm{min}$ ramp to $190{ }^{\circ} \mathrm{C}$, and a $30^{\circ} \mathrm{C} / \mathrm{min}$ ramp to $260^{\circ} \mathrm{C}$, where the temperature was held for $2 \mathrm{~min}$. The injector temperature was $250^{\circ} \mathrm{C}$, and the detector temperature was $260^{\circ} \mathrm{C}$. The carrier gas (hydrogen) flow rate was $1.1 \mathrm{~mL} / \mathrm{min}$, measured at $100{ }^{\circ} \mathrm{C}$, the split injector (1:50) was used at $250{ }^{\circ} \mathrm{C}$ and the volume of the sample injector was $1 \mu \mathrm{L}$. Fatty acid identification was performed by comparing the relative retention times of fatty acid methyl esters (FAMEs) peaks from the samples with standards. The results were recorded and processed using Clarity v.4.0.00.681 (DataApex) and expressed in relative percentages of each fatty acid. Two replicates were conducted for each sample.

Fatty acids (FA) was classified as short-chain fatty acid (SCFA from C2 to C4), medium-chain FA (MCFA from C6 to C12) and long-chain FA (LCFA from C14 to C24). The atherogenicity (AI) and thrombogenicity (TI) indices were calculated according to Eqs (2) and (3) (Batista et al., 2015, Sperry et al. (2018).

$$
\begin{aligned}
\mathrm{AI}= & (\mathrm{C} 12: 0+4 x \mathrm{C} 14: 0+\mathrm{C} 16: 0) / \Sigma \mathrm{MUFA} \\
& +\Sigma \operatorname{PUFA}(n-6) \text { and }(n-3), \\
\mathrm{TI}= & (\mathrm{C} 14: 0+\mathrm{C} 16: 0+\mathrm{C} 18: 0) /[0,5 \times \Sigma \mathrm{MUFA} \\
& +0.5 x \Sigma \mathrm{PUFA}(n-6)+3 x \Sigma \mathrm{PUFA}(n-3) \\
& +(n-3) /(n-6)] .
\end{aligned}
$$

\section{Microbiological stability and shelf life}

Microbiological stability and shelf life of the yogurts were determined at $0,7,14,21$, and 28 days, and the results were compared to the current Brazilian standards for fermented milks (Brasil, 2001).

\section{Sample preparation and microbiological analysis.} Aliquots of $25 \mathrm{~mL}$ of the samples from each yogurt were transferred into sterile bags, to which $225 \mathrm{~mL}$ of buffer peptone water
(BPW, Difco) was added aseptically, and the mixture was homogenized in a stomacher (240 bpm, VWR) for $2 \mathrm{~min}$. All analyses were performed in duplicate.

For lactic acid bacteria, $100 \mu \mathrm{L}$ of the serial 10 -fold dilution of the obtained suspension was inoculated into a double layer in De Man, Rogosa and Sharpe agar (MRS, VWR) and incubated at $37{ }^{\circ} \mathrm{C}$ for $72 \mathrm{hr}$ (Richter \& Vedamuthu, 2001). For yeasts and molds, $100 \mu \mathrm{L}$ of the serial 10 -fold dilution was spread onto DG18 agar (Liofilchem) with glycerol (Labchem, Laborspirit) and incubated at $25^{\circ} \mathrm{C}$ for 5 days (ISO, 2008). For coagulase-positive staphylococci, $1 \mathrm{~mL}$ of the serial 10-fold dilution was spread on the surface of Baird Parker agar (Himedia) supplemented with egg yolk tellurite and incubated at $37^{\circ} \mathrm{C}$ for $48 \mathrm{hr}$ (Lancette \& Tanini, 2001). The values were transformed into $\log \mathrm{CFU} / \mathrm{mL}$ of yogurt sample.

Coliforms at $37^{\circ} \mathrm{C}$ and Escherichia coli were enumerated using the SimPlate kit (Biocontrol ${ }^{\circledR}$, AOAC, 2012). Into the rehydrated medium with $9 \mathrm{~mL}$ of sterile distilled water, $1 \mathrm{~mL}$ of the suspension was inoculated, following the manufacturer instructions. The contents were poured into 84 -well plates and incubated at $37^{\circ} \mathrm{C}$ for 24 to $48 \mathrm{hr}$. The enumeration of coliforms was performed by counting of the wells with a medium color change, and the enumeration of $E$. coli was performed by counting of the wells in which fluorescence was observed after exposure to ultraviolet (UV) light at $365 \mathrm{~nm}$. The results were related according to the table provided by the manufacturer (AOAC, 2012).

The presence of Salmonella spp. was determined by an immunodiffusion test (Biocontrol ${ }^{\circledR}$, AOAC, 2003). First, $25 \mathrm{~g}$ of the sample was pre-enriched in $225 \mathrm{~mL}$ of BPW at $37^{\circ} \mathrm{C}$ for $24 \mathrm{hr}$. Then, an aliquot of $0.1 \mathrm{~mL}$ of the pre-enriched sample was added into the inoculation chamber containing one drop of iodine-iodide and gently shaken to mix. Afterward, one drop of preparation antibody (polyvalent $\mathrm{H}$ [flagellar] antibodies) was added into the motile chamber, and the units were incubated at 35 to $37^{\circ} \mathrm{C}$ for $24 \mathrm{hr}$. The immobilization of motile Salmonella results in development of well-defined bands of cells (ImmunoBand ${ }^{\mathrm{TM}}$ ).

\section{Bioactive compounds and antioxidant activity}

For the analysis of the bioactive compounds, the YRP and CY samples, both with strawberry pulp, on days 0 (zero) and 28 were evaluated. The total phenol was determined by the Folin-Ciocalteau method (adapted from Singleton, Orthofer, \& Lamuela-Raventos, 1999), and the results were expressed as mg of gallic acid equivalents/g of propolis (mg eq. GA/g). The flavonoid content was determined according to Jia, Tang, and Wu (1999), and the results were expressed as $\mathrm{mg}$ of quercetin equivalents/g of propolis ( $\mathrm{mg}$ eq. $\mathrm{QE} / \mathrm{g}$ ). The free radical sequestering activity was examined using the DPPH (2,2-diphenyl-1-picryl-hydrazyl) method and quantified according to Bobo-García et al. (2014), and the results were expressed as $\mathrm{mg}$ of Trolox equivalents/g of propolis extract (mg eq. Trolox/g). The ferric reducing ability of plasma (FRAP) assay was used for assessing the "antioxidant power" of the propolis samples, which was quantified using the method of Torre, B., Henderson, Nigam, and Owusu-Apenten (2015), and the results were expressed as mg of Fe(II) sulfate heptahydrate/g of propolis (mg eq. Fe(II)/g). Trolox was used as a standard at 50 to $500 \mu \mathrm{mol} / \mathrm{L}$ to generate a calibration curve. The percentage of inhibition (antioxidant activity) of free radicals was calculated according to Equation (4):

$$
\% \mathrm{DPPH}=\left[1-\frac{A \text { sample }-A \text { blank }}{A \text { control }-A \text { blank }}\right] \times 100,
$$


Table 1-Physical-chemical properties of the yogurt with red propolis (YRP) and conventional yogurt (CY), both with strawberry pulp, during storage at $4{ }^{\circ} \mathrm{C}$ for 28 days.

\begin{tabular}{lccc}
\hline Storage days & Sample & Titratable acidity & pH \\
\hline 0 & YRP & $1.28 \pm 0.04^{\mathrm{a}}$ & $4.35 \pm 0.05^{\mathrm{a}}$ \\
& CY & $1.27 \pm 0.06^{\mathrm{a}}$ & $4.30 \pm 0.06^{\mathrm{a}}$ \\
14 & YRP & $1.13 \pm 0.05^{\mathrm{b}}$ & $4.18 \pm 0.04^{\mathrm{b}}$ \\
& CY & $1.13 \pm 0.06^{\mathrm{b}}$ & $4.17 \pm 0.06^{\mathrm{b}}$ \\
28 & YRP & $0.85 \pm 0.05^{\mathrm{c}}$ & $4.03 \pm 0.05^{\mathrm{c}}$ \\
& CY & $0.83 \pm 0.06^{\mathrm{c}}$ & $4.00 \pm 0.00^{\mathrm{c}}$ \\
\hline
\end{tabular}

Note: Mean \pm standard deviation values in the same column followed by the same superscript letters are not significantly different $(P>0.05)$.

where $A$ sample is absorbance at $515 \mathrm{~nm}$ of $20 \mu \mathrm{L}$ of yogurts with $180 \mu \mathrm{L}$ DPPH solution after $40 \mathrm{~min}$; $A$ blank is absorbance at $515 \mathrm{~nm}$ of $20 \mu \mathrm{L}$ of water with $180 \mu \mathrm{L}$ methanol-water (80:20, $\mathrm{v} / \mathrm{v}$ ) after $40 \mathrm{~min}$; and $A$ control is absorbance at $515 \mathrm{~nm}$ of $20 \mu \mathrm{L}$ of water with $180 \mu \mathrm{L}$ DPPH solution after $40 \mathrm{~min}$.

Three replicates were conducted for each analysis.

\section{Statistical analysis}

The results obtained were subjected to an analysis of variance (ANOVA) followed by Tukey's test (5\% significance) to determine the significant differences between samples. The values were expressed as the mean \pm standard deviation. For the physicochemical analyses and fatty acid profiles, a $2 \times 3$ double factorial scheme was used, and the mean values were compared by Tukey's test $(5 \%$ significance), except for the fatty acids, which were subjected to the Fisher test at $1 \%$ and $5 \%$ probability. The R-studio software (R Core Team, 2017) was used for the analysis.

\section{Results and Discussion}

\section{Physicochemical characteristics}

The results of the evaluation of the physicochemical properties of the yogurts (Table 1) showed that the samples of YRP and CY did not present significant differences throughout the storage time under the conditions employed in this work $(P>0.05)$. The $\mathrm{pH}$ and acidity measurements showed variation (Table 1 ), and the $\mathrm{pH}$ varied from 4.35 to 4.03 for YRP and from 4.30 to 4.0 for CY.

The decreased $\mathrm{pH}$ and increased acidity are common in yogurts in refrigerated storage due to the metabolism of L. acidophilus, which from the fermentation of lactose caused the formation of lactic acid; since it is considered a homofermentative microorganism (Batista et al., 2015). This characteristic of acidophilic fermented milk is a factor that favors the inhibition of growth of undesirable microorganisms, such as deteriorating and pathogenic bacteria (Duarte, Cortez, Cortez, Franco, \& Macedo, 2016).

The control of $\mathrm{pH}$ in yogurt is very relevant, since it influences the syneresis by the excessive repulsion between charges (Molina et al., 2019). Also, the $\mathrm{pH}$ decrease affects the dissociation of casein micelle and reformation of a three-dimensional protein network (Uduwerella, Chandrapala, \& Vasiljevic, 2018). In addition, acidity is one the most important parameters in the perception of flavor in yogurt, and the desirable $\mathrm{pH}$ of yogurt is typically close to 4.4 . The preference of less acidic yogurt by some consumers is classified as less tasty (Batista et al., 2015).

The $\mathrm{pH}$ and acidity values found were within the Brazilian standards for fermented milks, which specifies values higher than 4.0 for $\mathrm{pH}$ and 0.6 to $1.5 \mathrm{~g}$ of lactic acid/100 $\mathrm{g}$ for acidity (Brasil, 2007).
Related to chemical composition, YRP presented: protein $(3.16 \pm 0.09)$, moisture $(87.44 \pm 0.53)$, ash $(0.70 \pm 0.01)$, carbohydrate $(23.56 \pm 0.58)$, and lipids $(3.28 \pm 0.20)$ (Table 2$)$. The addition of red propolis did not affect significantly $(P>0.05)$ the chemical composition of the YRP samples when compared with CY. From these results, it can be verified that protein and lipids values were within the Brazilian standards.

The presence of protein-lipid matrix in fermented milks contributes to the viability of probiotics throughout refrigerated storage and during the passage through the gastrointestinal (Silva et al., 2018). Also, the rheological properties of yogurt are affected by its dry matter content and the type of protein present in the yogurt gel matrix (Uduwerella et al., 2018)

\section{Fatty acids profile}

Regarding the fatty acids profiles, the results showed the presence of palmitic, oleic + elaidic, myristic, and stearic acids (Table 3) in the samples of YRP and in CY. In general, few differences were observed among the fatty acid profiles. Only the levels of caprylic acid show significant differences $(P<0.05)$, with the content reaching a value of 2.36 in the YRP and of 3.23 in the CY (Table 3).

The yogurts were characterized by levels of monounsaturated fatty acids, especially oleic acid. Monounsaturated fatty acids are protective against metabolic syndrome and cardiovascular disease risk factors (Garaffo et al., 2011; Sperry et al., 2018). Polyunsaturated fatty acids, especially linoleic acid, were observed too.

The addition, red propolis did not change the fatty acids profile in yogurt and only the levels of caprylic acid show significant differences (2.36 for YRP and 3.23 for CY). In general, the yogurts showed lower intermediate values for SCFA and MFCA (ranging between 4.72 and 3.29 , and 14.51 and $12.03 \mathrm{mg} / 100 \mathrm{~g}$ of lipids, respectively), and higher values for LCFA (ranging between 80.73 and $78.95 \mathrm{mg} / 100 \mathrm{~g}$ of lipids).

Concerning the saturated fatty acids, the samples showed levels of stearic and palmitic acids that suggest that the yogurts would have lower tendency to form clots in the blood vessels (Bortoluzzi et al., 2014, Sperry et al., 2018).

Among the PUFA, the conjugated linoleic acid (CLA) has become the focus of many studies, and the dairy products have considerable levels of CLA isomers, mainly linoleic and linolenic acids. These compounds are shown to be stable under normal heat treatment and storage conditions. In view of this fact, the identification of CLA in yogurt samples has become important because some of these bioactive compounds have been shown to modulate the inflammatory response, attenuate carcinogenesis, and improve bone mineralization and antidiabetic effects, among others (Bortoluzzi et al., 2014; Sperry et al., 2018; Yuan, Chen, $\& \mathrm{Li}, 2014)$.

In general, the highest proportion of saturated fatty acids is found in the milk fat, with chains containing 4 to 16 carbons, although the fermentation process can also contribute to the characteristics of the final product (Bortoluzzi et al., 2014). Thus, the chemical composition of a dairy food is directly influenced by the metabolic activity of the bacterium that interacts with the medium during its growth, converting certain components into products of its metabolism (Collomb, Schmid, Sieber, \& Wechsler, 2006).

In the evaluation of atherogenic (AI) and thrombogenic (TI) indices, the values found did not present significant differences $(P>0.05)$, demonstrating that the conservation of YRP samples resulted in the maintenance of $\mathrm{AI}$ and TI indices (Table 3), when compared with CY. In addition, the n6/n3 ratio showed 
Table 2-Chemical compositions of yogurt produced with red propolis (YRP) and conventional yogurt (CY), both with strawberry pulp.

\begin{tabular}{lccccc}
\hline Samples & Proteins (\%) & Ashes (\%) & Moisture (\%) & Carbohydrate (\%) & Lipids (\%) \\
\hline YRP & $3.16 \pm 0.09^{\mathrm{a}}$ & $0.70 \pm 0.01^{\mathrm{a}}$ & $87.44 \pm 0.53^{\mathrm{a}}$ & $23.56 \pm 0.58^{\mathrm{a}}$ & $3.28 \pm 0.20^{\mathrm{a}}$ \\
CY & $3.20 \pm 0.01^{\mathrm{a}}$ & $0.71 \pm 0.01^{\mathrm{a}}$ & $87.56 \pm 0.53^{\mathrm{a}}$ & $22.70 \pm 0.57^{\mathrm{a}}$ & $3.10 \pm 0.09^{\mathrm{a}}$ \\
Brazilian standards & 2.90 & - & - & - & 3.0 to 5.9 \\
\hline
\end{tabular}

Note: Mean \pm standard deviation values in the same column followed by the same superscript letters are not significantly different $(P>0.05)$.

Table 3-Fatty acids profile of conventional yogurt (CY) and yogurt with red propolis (YRP), both with strawberry pulp.

\begin{tabular}{lrr}
\hline Fatty acids & CY & \multicolumn{1}{c}{ YRP } \\
\hline Caproic acid (C6:0) & $4.72^{\mathrm{a}} \pm 0.61$ & $3.29^{\mathrm{a}} \pm 0.14$ \\
Caprylic acid (C8:0) & $3.23^{\mathrm{a}} \pm 0.02$ & $2.36^{\mathrm{b}} \pm 0.22$ \\
Capric acid (C10:0) & $5.68^{\mathrm{a}} \pm 0.89$ & $4.59^{\mathrm{a}} \pm 0.2$ \\
Lauric acid (C12:0) & $5.60^{\mathrm{a}} \pm 0.15$ & $5.08^{\mathrm{a}} \pm 0.63$ \\
Myristic acid (C14:0) & $13.89^{\mathrm{a}} \pm 0.22$ & $13.53^{\mathrm{a}} \pm 1.25$ \\
Miristoleic acid (C14:1) & $1.28^{\mathrm{a}} \pm 0.01$ & $1.10^{\mathrm{a}} \pm 0.12$ \\
Pentadecanoic acid (C15:0) & $1.22^{\mathrm{a}} \pm 0.13$ & $1.14^{\mathrm{a}} \pm 0.09$ \\
Palmitic acid (C16:0) & $37.64^{\mathrm{a}} \pm 1.93$ & $36.87^{\mathrm{a}} \pm 2.68$ \\
Palmitoleic (C16:1) & $1.47^{\mathrm{a}} \pm 0.11$ & $1.33^{\mathrm{a}} \pm 0.17$ \\
Stearic acid (C18:0) & $6.68^{\mathrm{a}} \pm 0.96$ & $6.61^{\mathrm{a}} \pm 0.68$ \\
Oleic + Elaidico acids (C18:1 n9c+t) & $16.57^{\mathrm{a}} \pm 1.13$ & $16.00^{\mathrm{a}} \pm 2.99$ \\
Linoleic acid (C18: 2n6) & $1.56^{\mathrm{a}} \pm 0.14$ & $1.92^{\mathrm{a}} \pm 1.34$ \\
Linoleic acid (C18: 3n3) & $0.42^{\mathrm{a}} \pm 0.05$ & $0.45^{\mathrm{a}} \pm 0.02$ \\
Short-chain fatty acids (SCFA) & $4.72^{\mathrm{a}} \pm 0.61$ & $3.29^{\mathrm{a}} \pm 0.13$ \\
Medium-chain fatty acids (MFCA) & $14.51^{\mathrm{a}} \pm 0.73$ & $12.03^{\mathrm{a}} \pm 1.05$ \\
Long-chain fatty acids (LCFA) & $80.73^{\mathrm{a}} \pm 1.35$ & $78.95^{\mathrm{a}} \pm 0.10$ \\
Monounsaturated fatty acid (MUFA) & $19.32^{\mathrm{a}} \pm 1.24$ & $18.43^{\mathrm{a}} \pm 3.28$ \\
Polyunsaturated fatty acid (PUFA) & $1.98^{\mathrm{a}} \pm 0.19$ & $2.37^{\mathrm{a}} \pm 1.32$ \\
Atherogenic index (AI) & $4.64^{\mathrm{a}} \pm 0.37$ & $4.62^{\mathrm{a}} \pm 1.46$ \\
Thrombogenic index (TI) & $4.86^{\mathrm{a}} \pm 0.57$ & $4.85^{\mathrm{a}} \pm 1.22$ \\
\hline
\end{tabular}

Notes: Fatty acids are expressed as $\mathrm{mg} / 100 \mathrm{~g}$ fat. Values are expressed as mean \pm standard deviation. Means with different lowercase superscripts in the same line indicate presence of statistical difference $(P<0.05)$ between yogurts. AI $=(\mathrm{C} 12: 0+4 \times \mathrm{C} 14: 0+\mathrm{C} 16$ : $0) / \Sigma$ MUFA $+\Sigma \operatorname{PUFA}(n-6)$ and $(n-3) ; \mathrm{TI}=(\mathrm{C} 14: 0+\mathrm{C} 16: 0+\mathrm{C} 18: 0) /[0.5 \times$ $\Sigma$ MUFA $+0.5 \times \Sigma \operatorname{PUFA}(n-6)+3 \times \Sigma \operatorname{PUFA}(n-3)+(n-3) /(n-6)$.

no significant difference between the samples, and, according to FAO (1994), values below 10 suggest desirable amounts to the diet for the prevention of cardiovascular risks.

\section{Microbial stability and shelf life}

The antimicrobial activity of propolis is mainly attributed to the presence of flavonoids, acids, esters, phenolic aldehydes, and ketones present in the resin (Luis-Villaroya et al., 2015). The mechanism is considered complex and can be attributed to the synergism between flavonoids, hydroxyls, and sesquiterpenes (Gonsales, Orsi, Fernandes Júnior, Rodrigues, \& Funari, 2006).

In this study, the antimicrobial activity in the YRP samples was measured in the yogurts under refrigeration $\left(4^{\circ} \mathrm{C} \pm 2{ }^{\circ} \mathrm{C}\right)$ at 0 (zero) 7, 14, 21, and 28 days (Table 4).

During the entire storage time, all samples showed the absence of Salmonella spp., coliforms and E. coli. Yeasts and molds and coagulase-positive staphylococci showed counts $<10 \mathrm{CFU} / \mathrm{mL}$ $(<1.0 \log \mathrm{CFU} / \mathrm{mL})$. These results demonstrated that all the samples were within the Brazilian standards for fermented milks (absence of Salmonella spp. in $25 \mathrm{~mL}$; coliforms at $45^{\circ} \mathrm{C}$, maximum of $10 \mathrm{MPN} / \mathrm{mL}$; yeasts and molds, maximum of $2 \times 10^{2}$ $\mathrm{CFU} / \mathrm{mL}$; and lactic acid bacteria, minimum of $10^{7} \mathrm{CFU} / \mathrm{mL}$ ) (Brasil, 2001).

Like our results, Cabral, Oldoni, Alencar, Rosalen, and Ikegaki (2012) reported that red propolis had excellent antimicrobial activity against $S$. aureus compared to other types of propolis studied. Mãrghitas, Dezmirean, and Bobis (2013), upon evaluating the antimicrobial activity toward Gram-negative and Gram-positive bacteria, verified that the use of red propolis extract inhibited the growth of the bacteria. The authors reported that antimicrobial activity is one of the most important characteristics of propolis, which results in its use in the prophylaxis of various diseases.

The enumeration of lactic acid bacteria in YRP produced values in accordance with Brazilian standards, that is, a minimum of $1.0 \times 10^{7} \mathrm{CFU} / \mathrm{mL}$ (Brasil, 2007). Differently, samples of CY containing potassium sorbate showed a drastic reduction in the population of these bacteria after 7 days of storage (Table 4). It was verified, therefore, that the extract of red propolis, even with its antimicrobial activities, did not have negative interactions with the lactic acid bacteria. Other authors reported lactic acid counts above $10^{7} \mathrm{CFU} / \mathrm{mL}$ in commercial yogurt and attributed this reduction to the chemical additive potassium sorbate (Oliveira, Lyra, \& Esteves, 2013). In this way, Fonseca et al. (2014) stated that the addition of a new additive or ingredient in a yogurt formulation should preserve the survival and viability of lactic acid bacteria through the established period of shelf life.

The ingestion of yogurts with probiotic is very important because it stimulates the proliferation of beneficial bacteria, to the detriment of the proliferation of harmful bacteria, reinforcing the natural defense mechanisms of the host (Li et al., 2016).

\section{Bioactive compounds and antioxidant activity}

The biological activities attributed to propolis, such as its antioxidant activity, have been widely studied. There is a positive correlation between the antioxidant capacity and the content of phenolic compounds in propolis (Cabral et al., 2009), especially in relation to the flavonoid content (Alencar et al., 2007) and the microbiological stability (Bodini, Sobral, Favaro-Trindade, \& Carvalho, 2013).

In this study, the antioxidant activity, phenols and flavonoid compounds, and stability were evaluated in three batches of the product $(\mathrm{B} 1, \mathrm{~B} 2$, and $\mathrm{B} 3)$ prepared with red propolis (YRP) and with potassium sorbate (CY), both with strawberry pulp, in three replicates at zero [T0] and 28 [T28] days. The antioxidant power of the propolis samples was compared with Trolox as a reference antioxidant (Table 5).

In the determination of the total phenols (Table 5), variation throughout the storage period from time zero [T0] to 28 days [T28] in the three yogurt batches was verified. At [T0], similar behaviors were observed among the batches, with the total phenol concentration between 5.49 and $5.73 \mathrm{mg}$ eq. GA/g of yogurt. However, this concentration was not verified during the total storage time, and in sample B1, the values culminated in a reduction accentuated at [T28]. In sample B2, a progressive decrease in the phenol content from [T0] to [T28] was verified (Table 5).

In the determination of flavonoids (Table 5), it was verified that the three batches of the product showed differences in the contents over time. At [T0], the B3 yogurt presented the highest flavonoid content, followed by B1 and B2. Yogurts B2 and B3 showed a small decreased in flavonoid contents at 28 days. 
Table 4-Molds and yeasts and lactic acid bacteria in conventional yogurt (CY) and in yogurt with red propolis (YRP), both with strawberry pulp, during storage at $4{ }^{\circ} \mathrm{C}$ for 28 days.

\begin{tabular}{|c|c|c|c|c|c|c|c|c|c|c|}
\hline \multirow[b]{3}{*}{ Microorganism } & \multicolumn{10}{|c|}{ Storage days/samples } \\
\hline & \multicolumn{2}{|c|}{0} & \multicolumn{2}{|c|}{7} & \multicolumn{2}{|c|}{14} & \multicolumn{2}{|c|}{21} & \multicolumn{2}{|c|}{28} \\
\hline & CY & YRP & CY & YRP & CY & YRP & CY & YRP & CY & YRP \\
\hline Molds and yeasts $(\log$ UFC/mL) & 1.4 & 1.3 & 1.2 & 1.2 & $<1.0$ & $<1.0$ & $<1.0$ & $<1.0$ & $<1.0$ & $<1.0$ \\
\hline Lactic acid bacteria $(\log \mathrm{CFU} / \mathrm{mL})$ & $7.54^{\mathrm{a}}$ & $7.60^{\mathrm{a}}$ & $7.44^{\mathrm{a}}$ & $7.64^{\mathrm{a}}$ & $3.09^{\mathrm{b}}$ & $7.55^{\mathrm{a}}$ & $1.08^{\mathrm{b}}$ & $7.41^{\mathrm{a}}$ & $0.49^{\mathrm{b}}$ & $7.25^{\mathrm{a}}$ \\
\hline
\end{tabular}

Note: Mean values in the same line followed by the same superscript letters are not significantly different $(P>0.05)$.

Table 5-Contents of total phenols and antioxidant activity (DPPH and FRAP) in three batches of yogurt prepared with Brazilian red propolis and strawberry pulp (B1, B2, and B3) during storage at $4{ }^{\circ} \mathrm{C}$ for 28 days.

\begin{tabular}{|c|c|c|c|c|c|c|c|c|}
\hline \multirow[b]{2}{*}{ Samples } & \multicolumn{2}{|c|}{ Total phenols ${ }^{a}$} & \multicolumn{2}{|c|}{ Flavonoids $^{b}$} & \multicolumn{2}{|c|}{$\mathrm{DPPH}^{\mathrm{c}}$} & \multicolumn{2}{|c|}{ FRAP $^{d}$} \\
\hline & 0 & 28 & 0 & 28 & 0 & 28 & 0 & 28 \\
\hline B1 & $5.73 \pm 0.86$ & $3.65 \pm 0.86$ & $0.18 \pm 3.54$ & $0.10 \pm 1.33$ & $0.99 \pm 0.71$ & $0.68 \pm 0.22$ & $13.01 \pm 0.15$ & $10.52 \pm 0.40$ \\
\hline B2 & $5.58 \pm 3.75$ & $4.39 \pm 0.82$ & $0.11 \pm 3.41$ & $0.09 \pm 3.41$ & $0.93 \pm 2.20$ & $0.85 \pm 2.55$ & $12.10 \pm 1.13$ & $10.93 \pm 2.38$ \\
\hline B3 & $5.49 \pm 0.15$ & $5.38 \pm 0.32$ & $0.28 \pm 3.39$ & $0.21 \pm 1.16$ & $1.09 \pm 0.81$ & $0.66 \pm 0.44$ & $13.81 \pm 1.51$ & $8.33 \pm 2.79$ \\
\hline
\end{tabular}

Note: \pm Standard deviation.

Total phenols (mg eq. GA/g of yogurt).

${ }^{b}$ Flavonoids (mg eq. QE/g of yogurt)

${ }^{\mathrm{C}} \mathrm{DPPH}$ (mg eq. Trolox/g of yogurt).

${ }^{\mathrm{d}}$ FRAP (mg eq. Fe(II)/g of yogurt).

Table 6-Contents of total phenols and flavonoids and antioxidant activity (DPPH and FRAP) in yogurt prepared with Brazilian red propolis and strawberry pulp $\left(\mathrm{YRP}_{1}\right)$, yogurt with red propolis only $\left(\mathrm{YRP}_{2}\right)$, and yogurt with potassium sorbate and strawberry pulp (control) (CY) stored at $4{ }^{\circ} \mathrm{C}$ for 28 days.

\begin{tabular}{|c|c|c|c|c|c|c|c|c|}
\hline \multirow[b]{2}{*}{ Samples } & \multicolumn{2}{|c|}{ Total phenols ${ }^{a}$} & \multicolumn{2}{|c|}{ Flavonoids $^{\mathbf{b}}$} & \multicolumn{2}{|c|}{$\mathrm{DPPH}^{\mathrm{c}}$} & \multicolumn{2}{|c|}{ FRAP $^{d}$} \\
\hline & 0 & 28 & 0 & 28 & 0 & 28 & 0 & 28 \\
\hline $\mathrm{YRP}_{1}$ & $5.49 \pm 0.04$ & $5.38 \pm 0.34$ & $0.28 \pm 3.39$ & $0.21 \pm 1.16$ & $1.09 \pm 0.81$ & $0.66 \pm 0.44$ & $13.81 \pm 1.51$ & $8.33 \pm 2.79$ \\
\hline $\mathrm{YRP}_{2}$ & $3.14 \pm 0.34$ & $2.79 \pm 1.06$ & $0.11 \pm 2.03$ & $0.14 \pm 2.75$ & $0.39 \pm 1.53$ & $0.36 \pm 2.48$ & $1.97 \pm 0.77$ & $1.75 \pm 0.43$ \\
\hline $\mathrm{CY}$ & $0.68 \pm 0.70$ & $1.14 \pm 0.65$ & $0.043 \pm 3.52$ & $0.098 \pm 3.99$ & $0.27 \pm 0.22$ & $0.44 \pm 1.56$ & $0.37 \pm 2.88$ & $0.60 \pm 2.80$ \\
\hline
\end{tabular}

${ }^{a}$ Total phenols (mg eq. GA/g of yogurt).

${ }^{b}$ Flavonoids (mg eq. QE/g of yogurt.

${ }^{c} \mathrm{DPPH}$ (mg eq. Trolox/g of yogurt).

${ }^{\mathrm{d}}$ FRAP (mg eq. Fe(II)/g of yogurt).

Regarding the antioxidant activity determined by the DPPH method (Table 5), the three batches of yogurt showed different behaviors during storage, with a decreased level at [T28], mainly for B3 and B1. Similar behavior was verified in the FRAP evaluation. For batches B1 and B2, the results were in accordance with the correlation coefficient $(R)$ obtained from the linear relationship between the parameters: $R=0.96$ for the linear relation between the total phenols and DPPH and $R=0.83$ for the linear relation between the flavonoids and FRAP.

From these results, it can be verified that between the three yogurt batches, B3 showed a more distinct behavior during storage, with higher levels at [T0] of bioactive compounds and antioxidant activities, except for the total phenols content. The differences between the behaviors of the three yogurt batches can be explained by the fact that they were prepared on different days using different strawberry pulps. Significant differences were found between the phenolic compound contents and antioxidant activities related to different yogurts and times (days) $(P<0.01 ; R>0.99)$.

According to Costa, Mendes, Araujo, and Pereira (2012), the antioxidant values in fruit pulps may vary according to maturation time, climate, the type of crop, and the region of cultivation.

Table 6 shows the results from the evaluation of the influence of strawberry pulp on the values of phenolic compounds (phenols and flavonoids) and on the antioxidant activity of yogurt stored under refrigeration for 28 days. Samples prepared with red propolis and strawberry pulp (YRP1) showed higher values of phenolic compounds (total phenols and flavonoids) and, consequently, higher antioxidant activity compared to yogurts prepared with only red propolis (YRP2) or with potassium sorbate and strawberry pulp (CY). These results demonstrated that the combination of the two ingredients in the samples (YRP1) increased the antioxidant activity.

The use of propolis in yogurt brings benefits to the health of the consumer, because, according to Andrade, Denadai, Oliveira, Nunes, and Narain (2017), phenolic compounds and flavonoids are the main components responsible for several biological activities, among them immunopotentiation, chemopreventive, and antitumor effects.

The red propolis resulted in greater inhibition of lipid peroxidation and sequestration of free radicals when compared to antioxidants most commonly used in foods, such as BHA, BHT and TBHQ, which have aroused concern about their toxicity (Lacerda, Tiveron, \& Alencar, 2011).

Furthermore, it can be verified that the YRP1 and YRP2 samples had higher values of phenolic compounds than did the CY samples (Table 6), and consequently, they showed greater 
antioxidant power. Concerning the behavior of the samples with propolis alone (YRP2), the case was very similar, with a slight decrease at [T28] in the phenolic content and antioxidant activity. The level of flavonoids (Table 6) increased slightly from [T0] to [T28].

\section{Conclusions}

The concentration of Brazilian red propolis extract used in the preparation of yogurt in this study showed higher phenol and flavonoid contents and better antioxidant activity than did CY prepared with potassium sorbate. Brazilian red propolis showed a great ability to inhibit microbial growth, and the counts were in accordance with Brazilian standards for fermented milks. It was verified, therefore, that the extract of red propolis, even with its antimicrobial activities, did not have negative interactions with the lactic acid bacteria, increasing the probiotic potential of yogurt. The addition of red propolis together with strawberry pulp or only red propolis resulted in higher levels of bioactive compounds and antioxidant activity than those found in CY.

The yoghurt produced in this study, preserved with red propolis, has demonstrated a potent natural product since the natural antioxidant presents health beneficial properties, and it has demonstrated an excellent natural additive. These results indicate that red propolis is an efficient alternative for use in yogurt production.

The knowledge acquired about these types of Brazilian propolis provides an important contribution to food research in the discovery of new functional products to the market, seeking a healthier diet. Therefore, the produced yogurt proves to be an innovative product with functional and probiotic potential to be placed in the market.

\section{Acknowledgments}

We thank the Coordenação de Aperfeiçoamento de Pessoal de Nivel Superior (CAPES), Brazilian government, for scholarship support (Finance Code 001), the Dr Cátia Ionara Santos Lucas (INSECTA laboratory, UFRB, Cruz das Almas, Brazil), and the technical team of the Polytechnic Institute of Bragança laboratory (Bragança, Portugal) for their support during the research.

\section{Author Contributions}

Marly Santos, Maria Estevinho, Carlos de Carvalho, Jorge Morais, Antonio Conceição, Vanessa Paula, and Rogeria Almeida designed the study and interpreted the results. Marly Santos, Rogeria Almeida, and Karina Magalhães-Guedes collected data and drafted the article. Karina Magalhães-Guedes revised the article.

\section{Conflict of Interest}

All authors state that there is no conflict of interest, including financial support, or other relationships with persons or organizations.

\section{References}

Alencar, S. M., Oldoni, T. L. C., Castro, I. S. R., Cabral, C. M., Costa-Neto, J. A., Rosalen, P. L., \& Ikegaki, M. (2007). Chemical composition and biological activity of a new type of Brazilian propolis: Red propolis. Journal of Ethnopharmacology, 113(2), 278-283 https://doi.org/10.1016/j.jep.2007.06.005

Andrade, K. J. S., Denadai, M., Oliveira, M. K., Nunes, M. L., \& Narain, N. (2017). Evaluation of bioactive compounds potential and antioxidant activity of brown, green and red propolis from Brazilian northeast region. Food Research International, 101, 129-138. https://doi.org/10.1016/j.foodres.2017.08.066

AOAC (2012). Association of Official Analytical Chemistry. Official methods of analysis. (19th ed). (1-3000). Gaithersburg, MD: Author.

AOAC (2003). Association of Official Analytical Chemistry. Rapid tests kits. Retrieved from http://www.aoac.org/tests/kits/microbiologykits.htm\#salmonella
Aryana, K. J., \& Olson, D. W. (2017). A 100-year review: Yogurt and other cultured dairy products. Journal of Dairy Science, 100, 9987-10013. https://doi.org/10.3168/jds.2017-12981 Asioli, D., Aschemann-Witzel, J., Caputo, V., Vecchio, R., Annunziata, A., Næsa, T., \& Varela, P. (2017). Making sense of the "clean label" trends: A review of consumer food choice behavior and discussion of industry implications. Food Research International, 99, 58-71. https://doi.org/10.1016/j.foodres.2017.07.022

Barros, L., Pereira, E., Calhelha, R. C., Duens, M., Carvalho, A. M., Santos-Buelga, C., \& Ferreira, I. C. F. R. (2013). Bioactivity and chemical characterization in hydrophilic and lipophilic compounds of Chenopodium ambrosioides L. Journal of Functional Foods, 5(2), 17321740. https://doi.org/10.1016/j.jff.2013.07.019

Batista, A. L. D., Silva, R., Cappato, L. P., Almada, C. N., Garcia, R. K. A., Silva, M. C., Cruz, A. G. (2015). Quality parameters of probiotic yogurt added to glucose oxidase compared to commercial products through microbiological, physical-chemical and metabolic activity analyses. Food Research International, 77, 627-635. https://doi.org/10.1016/ j.foodres.2015.08.017

Bobo-García, G., Davidov-Pardo, G., Arroqui, C., Virseda, P., Marín-Arroyo, M. R., \& Navarro, M. (2014). Intra-laboratory validation of microplate methods for total phenolic content and antioxidant activity on polyphenolic extracts, and comparison with conventional spectrophotometric methods. Journal of the Science of Food and Agriculture, 95(3), 204-209. https://doi.org/10.1002/jsfa.6706

Bodini, R. B., Sobral, P. J. A., Favaro-Trindade, C. S., \& Carvalho, R. A. (2013). Properties of gelatin-based films with added ethanol-propolis extract. LWT - Food Science and Technology, 51(1), 104-110. https://doi.org/10.1016/j.lwt.2012.10.013

Bortoluzzi, M., Nunes, C. R. Z., Silva, M. L., Kalschne, D. L., Naidoo, S., Mendonça, T. G., \& Brandão, W. A. P. L. N. T. M. (2014). Microbiological, physical-chemical and sensorial characterization of commercial yogurts with plum pulp. Brazilian Journal of Food Research, 5(1), 9-18. Retrieved from http://doi:10.14685/rebrapa.v5i1.136

Brasil. (2001). Agência Nacional de Vigilância Sanitária (ANVISA). Resolução de Diretoria Colegiada (RDC) $\mathrm{n}^{\circ} 12$, de 02 de janeiro de 2001. Regulamento Técnico para Padrões microbiológicos para alimentos. Brasília, DF.

Brasil. (2007). Ministério da Agricultura, Pecuária e Abastecimento (MAPA). Instrução Normativa no. 46, de 23 de outubro de 2007. Regulamento Técnico de Identidade e Qualidade para Leites Fermentados. Brasília, DF

Cabral, I. S. R., Oldoni, T. L. C., Alencar, S. M., Rosalen, P. L., \& Ikegaki, M. (2012). The correlation between the phenolic composition and biological activities of two varieties of Brazilian propolis (G6 and G12). Brazilian Journal of Pharmaceutical Sciences, São Paulo, 48(3), 557-564. https://doi.org/10.1590/S1984-82502012000300023

Cabral, I. S. R., Oldoni, T. L. C., Prado, A., Bezerra, R. M. N., Alencar, S. M., Ikegaki, M., \& Rosalen, P. L. (2009). Phenolic composition, antibacterial and antioxidant activity of Brazilian red propolis. Química Nova, 32, 1523-1527. https://doi.org/10.1590/ S0100-40422009000600031

Carocho, M., Barreiro, M. F., Morales, P., \& Ferreira, I. C. F. R. (2014). Adding molecules to food, pros and cons: A review on synthetic and natural food additives. Comprehensive Reviews in Food Science and Food Safety, 13(4), 377-399. https://doi.org/10.1111/1541-4337.12065

Carocho, M., Morales, P., \& Ferreira, I. C. F. R. (2015). Natural food additives: Quo vadis? Tiends in Food Science \& Technology, 45, 284-295. https://doi.org/10.1016/j.tifs.2015.06.007

Champagne, C. P., Adriano Gomes da Cruz, A. G., \& Daga, M. (2018). Strategies to improve the functionality of probiotics in supplements and foods. Current Opinion in Food Science, 22 160-166. https://doi.org/10.1016/j.cofs.2018.04.008

Cheung, T. T. L., Junghans, A. F., Dijksterhuis, G. B., Kroese, F., Johansson, P., Hall, L., \& De Ridder, D. T. D. (2016). Consumers' choice-blindness to ingredient information. Appetite, 106, 2-12. https://doi.org/10.1016/j.appet.2015.09.022

Collomb, M., Schmid, A., Sieber, R., \& Wechsler, D. (2006). Conjugated linoleic acids milk fat: Variation and physiological effects. International Dairy Journal, 16(11), 1347-1361. https://doi.org/10.1016/j.idairyj.2006.06.021

Costa, G. N. D. S., Mendes, M. F., Araujo, I. O. D., \& Pereira, C. D. S. S. (2012) Desenvolvimento de um iogurte sabor Juçaí (Euterpe edulis Martius): Avaliação físicoquímica e sensorial. Revista Eletrônica Teccen, 5, 43-58. Retrieved from http://doi/10.21727/ 198409932012.teccen.v5i2.43-58

Daleprane, J. B., \& Abdalla, D. S. (2013). Emerging roles of propolis: Antioxidant, cardioprotective, and antiangiogenic actions. Evidence-based complementary and alternative medicine, New York, 1-8. Retrieved from https://doi.org/10.1155/2013/175135

Daugsch, A., Moraes, C. S., Fort, P., \& Park, K. Y. (2008). Brazilian red propolis-chemical composition and botanical origin. Evidence-based complementary and alternative medicine, New York, 5, 347-363. Retrieved from https://doi.org/10.1093/ecam/nem057

De-Melo, A. A. M., Matsuda, A. H., \& Almeida-Muradian, L. B. (2012). Identity and quality of propolis from four regions of Brazil. Revista do Instituto Adolfo Lutz, São Paulo, 71, 540-548.

Duarte, M. C. K.H.; Cortez, N. M. S.; Cortez, M. A. S.; Franco, R. M., \& Macedo, N. C. (2016). Ação antagonista de Lactobacillus acidophilus frente a estirpes patogênicas inoculadas em leite fermentado. Journal of Bioenergy and Food Science, 3(1), 1-10. Retrieved from http://doi:10.18067/jbfs.v3i1.79

FAO - Food and Agriculture Organization. (1994). Fats and oils in human nutrition. Roma: Author. Retrieved from http://www.fao.org/3/V4700E/V4700E08.htm\# Metabolism $\% 20$ of $\% 20$ fatty $\% 20$ acids

Fonseca, C. M., Boari, C. A., Domingues, P. H. F., Meira, D. P., Fernandes, L. S. F., \& Dumont, M. A. (2014). Iogurte produzido com cajuí (Anacardium othonianum Rizz). Semina: Agrarian Sciences, Londrina, 35(4), 1829-1836.

Freires, I. A., De Alencar, S. M., \& Rosalen, P. L. (2016). A pharmacological perspective on the use of Brazilian Red Propolis and its isolated compounds against human diseases. European Journal of Medicinal Chemistry, 110, 267-279. https://doi.org/10.1016/ejmech.2016.01.0332016

Garaffo, M. A., Vassallo-Agius, R., Nengas, Y., Lembo, E., Rando, R., Maisano, R., \& Giuffrida, D. (2011). Fatty acids profile, atherogenic IA and thrombogenic IT health lipid indices, of raw roe of blue fin tuna Thunnus thynnus L. and their salted product "Bottarga." Food Nutrition and Science, 2, 736-743. https://doi.org/10.4236/fns.2011.27101

Gonsales, G. Z., Orsi, R. O., Fernandes Júnior, A., Rodrigues, P., \& Funari, S. R. C. (2006) Antibacterial activity of propolis collected in different regions of Brazil. Journal of Venomous Animals and Toxins including Tropical Diseases, 12, 276-284.

Hill, C., Guarner, F., Reid, G., Gibson, G. R., Morenstein, D. J., Pot, B., ... Sanders, M. E. (2014). Expert consensus document: The International Scientific Association for Probiotics and Prebiotics consensus statement on the scope and appropriate use of the 
term probiotic. Nature Reviews Gastroenterology \& Hepatology, 11, 506-514. https://doi.org/ $10.1038 /$ nrgastro.2014.66

ISO (2008). ISO 21527-2, International Standards Organization. Microbiology of food and animal feeding stuffs- Horizontal method for the enumeration of yeasts and moulds-Part 2: Colony count technique in products with water activity less than or equal to 0.95 .

Jansen-Alves, C., Krumreich, F., Zandoná, G. P., Gularte, M. A., Borges, C. D., \& Zambiazi, R. C. (2019). Production of propolis extract microparticles with concentrated pea protein for application in food. Food and Bioprocess Technology, 12(5), 729-740. https://doi.org/ 10.1007/s11947-019-2246-2

Jia, Z., Tang, M., \& Wu, J. (1999). The determination of flavonoid contents in mulberry and their scavenging effects on superoxide radicals. Food Chemistry, 64(4), 555-559.

Koc, A. N., Silici, S., Mutlu-Sariguzel, F., \& Sagdic, O. (2007). Antifungal activity of propolis in four different fruit juices. Food Technology and Biotechnology, 45(1), 57-61.

Lacerda, R. C. C., Tiveron, A. P., \& De Alencar, S. M. (2011). Própolis e Segurança Alimentar Segurança Alimentar e Nutricional, 18(2), 99-106. https://doi.org/10.20396/san.v18i2.8634682 Lancette, G. A., \& Tanini, S. R. (2001). Staphylococcus aureus and staphylococcal enterotoxins. In F. P. Downes \& K. Ito (Eds.), Compendium of methods for the microbiological examination of foods (4th ed., pp. 387-403). Washington, DC: American Public Health Association.

Li, J., Sung, C. Y. J., Lee, N., Ni, Y., Pihlajamäki, J., Panagiotou, G., \& El-Nezami, H. (2016) Probiotics modulated gut microbiota suppresses hepatocellular carcinoma growth in mice. Proceedings of the National Academy of Science of United States of America, 113(9), E1306-E1315. https://doi.org/10.1073/pnas.1518189113

Liu, D. (2018). Effect of Fuzhuan brick-tea addition on the quality and antioxidant activity of skimmed set-type yoghurt. International Journal of Dairy Technology, 71(S1), 22-23. https://doi.org/10.1111/1471-0307.12395

Lopez, B. G., de Lourenço, C. C., Alves, D. A., Machado, D., Lancelotti, M., \& Sawaya, A. C. H. F. (2015). Antimicrobial and cytotoxic activity of red propolis: An alert for its safe use Journal of Applied Microbiology, 119, 677-687. https://doi.org/10.1111/jam.12874

Luis-Villaroya, A., Espina, L., García-Gonzalo, D., Bayarri, S., Pérez, C., \& Pagán, R. (2015) Bioactive properties of a propolis-based dietary supplement and its use in combination with mild heat for apple juice preservation. International Journal of Food Microbiology, 205, 90-97. https://doi.org/10.1016/j.ijfoodmicro.2015.03.020

Mãrghitas, L. A., Dezmirean, D. S., \& Bobis, O. (2013). Important developments in Romanian propolis research. Evidence-Based Complementary and Alternative Medicine, 13, 9-18. https://doi.org/10.1155\%2F2013\%2F159392

Molina, C. V., Lima, J. G., Moraes, I. C. F., \& Pinho, S. C. (2019). Physicochemical characterization and sensory evaluation of yogurts incorporated with beta-carotene-loaded solid lipid microparticles stabilized with hydrolyzed soy protein isolate. Food Science and Biotechnology, 28(1), 59-66. https://doi.org/10.1007/s10068-018-0425-y

Morais, M., Moreira, L., Feas, X., \& Estevinho, L. M. (2011). Honeybee-collected pollen from five Portuguese natural parks: Palynological origin, phenolic content, antioxidant propertie and antimicrobial activity. Food Chemical and Toxicology, 49(5), 1096-1101.

Oliveira, F. M., Lyra, I. N., \& Esteves, G. S. G. (2013). Microbiological and physico-chemical evaluation of strawberry yoghurts industrialized and marketed in the municipality of LinharesES. Brazilian Journal of Agroindustrial Products, Campina Grande, 15(2), 147-155.

Park, Y. K., Ikegari, M., Abreu, J. A. S., \& Alcici, N. M. F. (1998). Study of the preparation of extracts of propolis and its applications. Ciência e Tecnologia de Alimentos, 3(18), 313-318.
Pontes, M. L. C., Vasconcelos, I. R. A., Diniza, M. F. F. M., \& Pessôa, H. L. F. (2018). Chemical characterization and pharmacological action of Brazilian red propolis. Acta Brasiliensis, 1(1), 34-39. https://doi.org/10.22571/\%202526-433868

R Core Team. (2017). R: A language and environment for statistical computing. Vienna, Austria: R Foundation for Statistical Computing. Retrieved from http://www.R-project.org/

Ranadheera, C. S., Naumovski, N., \& Ajlouni, S. (2018). Non-bovine milk products as emerging probiotic carriers: Recent developments and innovations. Current Opinion in Food Science, 22, 109-114. https://doi.org/10.1016/j.cofs.2018.02.010

Ribeiro, M. M. (2010). Estudo de mercado de iogurte da cidade de Belo Horizonte/MG. Revist Ceres, 57(2), 151-156. https://doi.org/10.1590/S0034-737X2010000200003

Richter, R. L., \& Vedamuthu, E. R. (2001). Milk and milk products. In F. P. Downes \& K. Ito (Eds.), Compendium of methods for the microbiological examination of food (4th ed., pp. 483-493). Washington, DC: American Public Health Association.

Robert, N. F. (2008). Dossiê Técnico. Fabricação de iogurtes. Rede de Tecnologia do Rio de Janeiro, REDETEC. Copyright, Serviço Brasileiro de Respostas Técnicas. Retrieved from http://www.respostatecnica.org.br

Silva, F. C., Alencar, S. M., Thomazini, M., Balieiro, J. C. C., Pittia, P., \& FavaroTrindade, C. S. (2013). Assessment of production efficiency, physicochemical properties and storage stability of spray-dried propolis, a natural food additive, using gum Arabic and OSA starch-based carrier systems. Food and Bioproducts Processing, 9(1), 28-36. https://doi.org/10.1016/j.fbp.2012.08.006

Silva, H. L. A., Balthazar, C. F., Esmerino, E. A., Neto, R. P. C., Rocha, R. S., Moraes, J .. Cruz, A. G. (2018). Partial substitution of $\mathrm{NaCl}$ by $\mathrm{KCl}$ and addition of flavor enhancers on probiotic Prato cheese: A study covering manufacturing, ripening and storage time. Food Chemistry, 248, 192-200. https://doi.org/10.1016/j.foodchem.2017.12.064

Singleton, V. L., Orthofer, R., \& Lamuela-Raventos, R. M. (1999). Analysis of total phenols and other oxidation substrates and antioxidants by means of Folin-Ciocalteu reagent. Methods in Enzymology, 299, 152-178.

Sperry, M. F., Silva, H. L. A., Balthazara, C. F., Esmerino, E. A., Verruck, S., Prudencio, E. S., ... Cruz, A. G. (2018). Probiotic Minas Frescal cheese added with L. casei 01 Physicochemical and bioactivity characterization and effects on hematological/biochemical parameters of hypertensive over-weighted women-A randomized double-blind pilot trial. Journal of Functional Foods, 45, 435-443. https://doi.org/10.1016/j.jff.2018.04.015

Torre, La, B., A. A. S., Henderson, T., Nigam, P. S., \& Owusu-Apenten, R. K. (2015). A universally calibrated microplate ferric reducing antioxidant power (FRAP) assay for foods and applications to Manuka honey. Food Chemistry, 174, 119-123. https://doi.org/10.1016/ j.foodchem.2014.11.009

Tsukatani, T., Suenaga, H., Higuchi, T., Akao, T., Ishiyama, M., Ezoe, K., \& Matsumoto, K. (2008). Colorimetric cell proliferation assay for microorganisms in microtiter plate using water-soluble tetrazolium salts. Journal of Microbiological Methods, 75, 109-116.

Uduwerella, G., Chandrapala, J., \& Vasiljevic, T. (2018). Preconcentration of yoghurt base by ultrafiltration for reduction in acid whey generation during Greek yoghurt manufacturing. International Journal of Dairy Technology, 71, 71-80. https://doi.org/10.1111/1471-0307.12393

Yildiz, E., \& Ozcan (2019). Functional and textural properties of vegetable-fibre enriched yoghurt. International Journal of Dairy Technology, 72(2), 199-207. https://doi.org/10.1111/ 1471-0307.12566

Yuan, G. F., Chen, X. E., \& Li, D. (2014). Conjugated linolenic acids and their bioactivities: A review. Food and Function, 5, 1360-1368. 